European journal of American studies

Special Issue: Animals on American Television

\title{
Wild Animation: From the Looney Tunes to Bojack Horseman in Cartoon Los Angeles
}

Laurel Schmuck

\section{(2) OpenEdition \\ Journals}

Electronic version

URL: https://journals.openedition.org/ejas/12459

DOI: 10.4000/ejas.12459

ISSN: 1991-9336

Publisher

European Association for American Studies

Electronic reference

Laurel Schmuck, "Wild Animation: From the Looney Tunes to Bojack Horseman in Cartoon Los Angeles", European journal of American studies [Online], 13-1 | 2018, Online since 26 June 2018, connection on 08 July 2021. URL: http://journals.openedition.org/ejas/12459 ; DOI: https://doi.org/10.4000/ejas. 12459

This text was automatically generated on 8 July 2021 .

Creative Commons License 


\title{
Wild Animation: From the Looney Tunes to Bojack Horseman in Cartoon Los Angeles
}

\author{
Laurel Schmuck
}

The figure for nature in language, animal, was transformed in cinema to the name for movement in technology, animation. And if animals were denied capacity for language, animals as filmic organisms were themselves turned into languages, or at least, into semiotic facilities. The medium provided an alternative to the natural environment that had been destroyed and a supplement to the discursive space that had never opened an ontology of the animal. (Lippit 196-197)

BoJack Horseman (Netflix, 2014-), an animated adult television show about a washed-up actor who happens to be a horse, imagines Los Angeles as home to a society of humans and animals living together as equals. Creatures such as cats, turtles, giraffes, and giant insects sport human fashions and work human jobs, but they all retain some of their most stereotypical animal attributes. The show's protagonist is an animal who has been deemed obsolete time and again. Bred for work, transportation, and finally racing, horses are becoming superfluous in contemporary society, since there are fewer demands for them in the much-changed industries of transportation, agriculture, and sport. Names like Secretariat, the iconic racehorse who won the Triple Crown in 1973 and who plays a significant role in the show, are phenomena of the past. In BoJack Horseman, the horse outlives the utility of his animal identity as BoJack, an alcoholic womanizer living in the Hollywood hills. His whole life, he has aspired to be like Secretariat, or, at the very least, to play his role in a movie. In the show, Secretariat's life ended in despair and suicide, and his legacy portends a similar fate for BoJack. After continual bouts of depression and existential strife build up to an attempted suicide in the desert, BoJack regains hope upon seeing an inspirational sight: "wild" mustangs running free. Albeit depicted in characteristic absurdity, these "wild" horses wear stylish running shorts and sneakers. BoJack is the culmination of all things animal in society. He cannot be fulfilled; he is set up for failure. Even his success, epitomized by his 1980s TV show, in which he played an adopted father to human children, is based on the hilarious impossibility of traditional happiness for a horse. BoJack's Los Angeles 
is a space full of half-assimilated human-animals who retain traits of the animal and live human lives.

2 In this essay, I will trace what Akira Lippit calls the "animetaphor" in cartoon Los Angeles. I understand Lippit's term as a moving image of the re-membered animal which projects a collective anxiety of oblivion for all animals, including humans. ${ }^{1} \mathrm{I}$ will begin by discussing this theme in the context of early cinema and the philosophical and psychological movements that accompanied it. I will then investigate more contemporary examples of these models in three case studies-Chuck Jones' characters in the Looney Tunes (1930-1969), Who Framed Roger Rabbit (1988), and BoJack Horsemanto explore the imagined city of Los Angeles as a cartography of animal ghosts, invented and re-invented as semiotic machines, which force us to look at animals as ourselves and at ourselves as animals. Mechanisms of mass cultural memory are at work in the cinematic history of Los Angeles, and animals are the projections of those memories. The link between psychoanalysis, the emergence of cinema, and modernism during the early part of the twentieth century serves as the philosophical-aesthetic background for my approach to social and artistic themes that haunt cinematic and real space in Los Angeles through the movement of animated animals.

\section{Psychoanalysis and Memory}

3 The link between psychoanalysis, the emergence of cinema, and modernism serves as the philosophical-aesthetic background for my approach to social and artistic themes that haunt cinematic and real spaces in Los Angeles and their relation to the movement of animated animals. BoJack Horseman, the central text studied in this article, is preoccupied with the concerns of psychoanalysis. Questions of responsibility and memory make up the central questions that haunt BoJack: Do the traumas he experienced during his childhood make him who he is, or is he personally responsible for his anxiety, despair, and wrongdoing? Is there something in his psychological makeup that his mother and father bequeathed him and which makes him the way he is? Can he justifiably erase the memories of his father and mother, and live in Los Angeles as an orphan, free of the aforementioned effects from his childhood?

In History of Forgetting: Los Angeles and the Erasure of Memory (1997), Norman Klein studies the "phantom limbs" left behind after destructive policies erase communities. A specialist in the history of cartoons, he compares the process of animation to the process of erasure in the city's culture: “[W]hile researching on animation for ten years, I noticed that the drawings and pencil effects made before a cartoon was finished often betrayed more about the real intentions than what finally showed on the movie screen" (3). Klein is drawn to the idea of the creation of mass culture, which is directly linked with erasure: "The sheer numbers of erased versions, and the many animation crafts people I interviewed utterly changed my understanding of what takes place when mass culture is produced .... The same clearly was true of Los Angeles" (3). Although I will not investigate the production histories of specific cartoons, I will analyze the psychological and cultural origins of certain characters, most notably BoJack, as well as scenes and plots which reveal similar phantom limbs in Los Angeles' cultural cartography.

Klein mentions the process of mass culture creation above, and that is exactly what I will engage with in psychoanalytic terms. Klein goes on to discuss the mechanism of 
individual forgetting or erasure in the psychological concept of the imago-"an idealized face left over from childhood-a photograph, the color of mother's dress on the day she took ill (the photological trace)" (3-4). These personal fictions are what make up mass culture. When investigating such images, we must recognize their connection with memory and fiction. They are creations whose context is lost: "the details around get lost, as if they were haunted, somewhat contaminated, but empty" (Klein 4). Like a romantic fragment, the images of animation are both authored and authorless. In his famous essay "Death of the Author" (1967), Roland Barthes proposes that

writing

is a space of many dimensions, in which are wedded and contested various kinds of writing, no one of which is original: the text is a tissue of citations, resulting from the thousand sources of culture" (142). A work of animation is almost a literalized demonstration of his theory. "[T]he hand, cut off from any voice, borne by a pure gesture of inscription ... traces a field without origin-or which, at least, has no other origin than language itself" (Barthes 142). In the animated pictures discussed here,

literal hands are creating the text out of a moving image of animal. Although an animated character may be created by an individual, the figure is drawn and redrawn by numerous hands, all of which are ultimately absent in the final product.

6 I propose to read cartoons as mass-authored texts. They cast a fictive light from a source akin to the unconscious: "Imagos are the sculpture that stands in the foreground next to negative space. Imagos are the false light that defines chiaroscuro" (Klein 4). The interplay between negative space, false memory, and erasure is important for the animal in cinema and especially in animation. We are, after all, remembering the animal. The disappearance of the wild animal from our lives, or the extinction or endangerment of species, often spurs cartoon representations of animals. "At once territories and metamorphoses have been taken from [man]-the unconscious is the individual structure of mourning in which this loss is incessantly, hopelessly replayed-animals are the nostalgia for it," Jean Baudrillard has explained (139). When creating animations, we project a false light through which to view ourselves and our histories.

7 The first moving pictures were often used to reproduce animal movement, such as Eadweard Muybridge's zoopraxiscope and its depiction of all kinds of animals' gaits. Likewise, the first animated works often featured animals, such as Windsor McKay's famous "Gertie the Dinosaur," whose premise was to use the new technology of cartoon animation to reanimate a dinosaur from the natural history museum in New York City. McKay's dinosaur is widely recognized as "the first anthropomorphized animal cartoon character" (Eagan 33). Purportedly, McKay (and presumably his audiences) believed that animating extinct species of animals was a public service, a necessary role of technology. This role is just what Lippit describes in an expansion of John Berger's ideas: "Modernity can be defined by the disappearance of wildlife from humanity's habitat and by the reappearance of the same in humanity's reflections on itself: in philosophy, psychoanalysis, and technological media such as the telephone, film and radio" (3).

8 Akira Lippit concludes his vast study of the disappearing animal with an exciting speculation about cinema, which combines its genesis with that of psychoanalysis and at the same time conflates cinema studies with critical theory on animals: "[C]inema, which arrives with psychoanalysis in 1895 , provides, perhaps, the proper metaphor for 
the impossible metaphor, the animetaphor" (196). Lippit also ties together Freud's notion of unheimlich and memory with both cinema and the disappearing animal: "The function of unheimlich reproduction, ... the dynamics of animation and projection, ... and the fundamental properties of memory can be seen as the basis of cinema, but also of the animal" (196).

9 Numerous scholars have linked photography to the uncanny because it "mechanically repeats what could never be repeated existentially" (Barthes 4). Tom Gunning has developed this idea, remarking that photography was "experienced as an uncanny phenomenon, one which seemed to undermine the unique identity of objects and people, endlessly reproducing appearances of objects, creating a parallel world of phantasmatic doubles alongside the concrete world of the senses verified by positivism" (42-43). Where literature and language are vessels for so-called humanness, and photography is the means of mourning the dead, cinema becomes the expression of a non-linguistic self, of a life through movement: "Cinema is like an animal; the likeness a form of encryption. From animal to animation, figure to force, poor ontology to pure energy" (Lippit 196). This physical movement is what leads Lippit to his tentative comparison of cinema to the animal: "cinema may be the technological metaphor that configures mimetically, magnetically, the other world of the animal" (Lippit 196). Paul Wells has argued that cartoon animation, especially featuring animal characters, offers an additional degree of difference from the human world: "It is possible to view animation as an approach that inevitably facilitates a representational difference, and that intrinsically interrogates orthodox positions, embedded ideology, and epistemological certainty per se" (5). In this essay, these ideas culled from film studies will also be applied to television. Since the main object of this study is to explore animated animal figures as they reflect problems of memory in the imagined landscape of Los Angeles, I will not distinguish between different genres of animation.

\section{Shklovskian Estrangement}

I propose to expand Lippit's suggestion concerning the interrelation between animals and cinema by adding the literary theory of "estrangement" proposed by Viktor Shklovsky in 1916 to the above web of animating forces. Alongside Freud's notion of unheimlich, which means not only weird or unfamiliar, but also wild, in the sense of an undomesticated animal, Shklovsky's theory of estrangement relies mostly on the evocation of animal voices and figures. Like Freud's unheimlich, Shklovsky's theory invokes a negative aesthetics, characteristic of modernism, which was marked by a "subtraction of meaning and value rather than by an act of creation" (Emerson 639). Shklovsky was "enamored of Futurism, modernity, fast machines, and the efficiency of the device" (Emerson 638), but he detested the automatization of human perception (i.e., the recognition of an object or an image without active or participatory creative perception). In a rebellion against Cartesian automata as animals, Shklovsky channels the animal gaze as a way to disrupt automatization: "A body whose perception has become automatized ceases to be aroused by stimuli in its environment-either strategically for self-defense or pleasurably for art, play, or Eros" (Emerson 645). Like Freud's unheimlich, which reveals what is hidden from the self and marks the return of repressed material, Shklovsky's device makes something unrecognizable (hidden or unknown) for it to be revealed as something unfamiliar and therefore creative-this 
process also reveals the true properties of an object.The individual encounter with an image both concerns the individual and repressed meaning.

11 Cinema implicates more than one individual in its making and viewing (Cavalcanti 84), and can be linked with the unconscious, as early cinema theorists such as Sergei Eisenstein and Dziga Vertov suggest: "the structure of transference perhaps best confirms the rapport between film and the unconscious" (Lippit 24). Thus, Lippit argues that "cinema is no longer a machine like other machines. Transference allows films to communicate" (24-25). Since transference is a method of communication that makes language superfluous, cinema can be linked to the animal by the same logic (Lippit 25).

The linkage between technology and the unconscious was also proposed by other thinkers of the time, especially in Russia. In her study of technology and the Russian avant-garde, Julia Vaingurt explains how cinema and radio were perceived this way by thinkers of the 1920s. For example, the futurist poet Velimir Khlebnikov wrote about "the influence of a past event on subsequent events that take place in the same geographic location ... through absence" (Vaingurt 117). I would venture to argue that Freud's unheimlich, Shklovsky's estrangement, and the fascination with animal movement of early cinema and cartoon animation suggest a particular function of cinema, and even more so cartoon animation, to remind us of repressed sensations and images from our collective unconscious.

\section{The Fabulist Tradition}

Chuck Jones, the creator of Bugs Bunny, Daffy Duck and Pepé Le Pew (among others), begins his memoir Chuck Amuck (1989) with a scenario reminiscent of Jacques Derrida's famous chapter about being caught in his cat's gaze. Derrida stresses the material presence of his cat, who is different from the vast lineage of literary and folkloric cats: "I must immediately make it clear, the cat I am talking about is a real cat .... It isn't the figure of a cat. It doesn't silently enter the bedroom as an allegory for all the cats on the earth, the felines that traverse our myths and religions, literature and fables" (6).

Chuck Jones, on the other hand, in his encounter with the ostensibly "real" cat Johnson, credits the fabulist tradition (Aesop) as the source for his desire to animate (13). However, he contradicts himself somewhat when he elaborates on the process of animation, which he notes means to "invoke life" (13). He starts by claiming, à la Aesop, that it is easier to make animals seem human than to make humans seem human (13). Just like Shklovsky's example of the stone's "stoniness" (xi) being revealed only when it is made unrecognizable as a stone, the humanness we imagine in our true nature is not expressed unless humans are made unrecognizable (i.e., disguised as animals).

An attention to the reversal of automated recognition characterizes Chuck Jones' approach to animation throughout his description of the encounters he had with the cat named Johnson in his childhood. He notes that Johnson could only be drawn and understood through the observation of his idiosyncratic difference to all the expected attributes and behaviors of a "cat." He remarks: "Although he wore a cat uniform, he contemptuously disdained all forms of feline behavior-an immortal, surely; an individual absolutely" (23). He then rebuts his earlier suggestion that animators are akin to Aesop, as he writes of his Uncle Lynn's storytelling as the genesis for his own 
appreciation of narrative. He enjoyed Uncle Lynn's stories because they never conveyed a moral or message. They were stories about animals, but they were more akin to anecdotes or jokes, and Chuck describes his enjoyment as the "love of listening" (27). I would argue that Jones followed the example of Uncle Lynn in his cartoons, whereas Disney animators often attempt to use cartoons to impress upon their audiences specific messages. This divorce from a didactic orientation is characterized by an attention to pure movement. According to Jones, "We are how we move" (14). This antididactic drive is, however, not bereft of literature. Jones seamlessly incorporates poetry and modernist prose as he describes his first encounter with Johnson. Alluding to Carl Sandburg's "Fog" (1916), Jones credits his realization of "difference" between cats to the appearance of Johnson who "padded in on little fog feet" and goes on to draw on James Joyce's "mckgnaow" when describing Johnson's mewing (14).

Both Derrida and Jones encounter the wildness of their cat counterparts in their writings. It is this wildness, which Akira Lippit sees remembered in art, as wildness has disappeared from our everyday lives and is reproduced as pure energy or pure movement in cinema and animation. Similarly, the concept of wildness ascribes wholeness to the fragmented, as Gary Snyder explains in The Practice of the Wild (1990): "Wilderness is a place where the wild potential is fully expressed, a diversity of living and nonliving beings flourishing according to their own sorts of order" (12). When imagining the ecology of contemporary urban culture, such as is played with in BoJack Horseman, this distinction between wholeness and homogeneity is important: "When an ecosystem is fully functioning, all the members are present at the assembly. To speak of wilderness is to speak of wholeness" (Snyder 12). If every part of a heterogeneous ecology flourishes, then wholeness is achieved.

This type of fragmented wholeness can be seen in the imaginative ecosystem of Bojack Horseman's Los Angeles, where the diversity of species, who even retain some of their often now-useless evolved traits, seems to point to unity rather than disunity. The assumption that a cat and a turtle can play major roles in a talent agency and in the cinema industry, respectively, shows that society functions smoothly although each of these animals evolved for very different occupations. They were still able to "make it" in Los Angeles, because Los Angeles is a place where malformed or misdirected animals come to make their living.

In this notion of wild ecology, wholeness is achieved through fragmentation and difference. In narrative, this idea translates to uninhibited expression rather than didacticism. The fabulist use of animals is transmuted into directionless movement, cartoon animation. ${ }^{2}$ Many Disney cartoons rely more on the former use, although they sanctify the folkloric sources upon which they draw (e.g., the grasshopper learns and does not die [Cavalcanti 88]). Ultimately, they strive to construct a coherent worldview that does not account for unresolved differences. This approach implicitly "den[ies] wild nature as an integral part of the biosphere at the world level and as part of individual character at the personal level" (Murphy 125).

Disney's interpretation of the fabulist tradition to reinforce homogeneity and sameness stands in stark contrast to the attention to difference that characterizes the cartoons analyzed in this study. Murphy's concept of wildness ("active manifestations contingent, indeterminate, and contextually particularistic, and thus continuous 
demonstrations of the principle of difference" [125-126]) permeates Chuck Jones' writings about the genesis of Johnson the cat, his first cartoon.

BoJack Horseman absorbs elements from Chuck Jones as well as from the fabulist tradition. However, the associations of the fables-turtles are slow and careful, etc.are reduced to insignificant qualities, which are exploited for humorous asides and rarely contribute to the plot, and certainly don't express a didactic message. Examples of this include: the chicken dressed as a teeny bopper who lays an egg in fear when BoJack yells at her; BoJack's tendency to neigh loudly during sex; the cow-waitress at the diner who flaunts her disdain whenever she is obliged to serve steak or squirt milk into her patrons' coffee; Mr. Peanut Butter's (the dog's) inexplicable rage whenever he sees the mail man; and his habit of keeping framed pictures of his friends' rear ends rather than their faces in his house. None of these animal attributes contribute to the central plot of a given episode, but they account for much of the humor in a television show whose plots are largely psychological, and which often deal with serious subjects like despair, suicide, and substance abuse.

Indeed, BoJack's story is the only one which may be read as an extended fable, as his eternal flight from the threat of oblivion. In a casting for a bio-pic centering on his childhood hero Secretariat, BoJack's audition partner asks, "What are you running from?" "Nothing. I'm terrified of nothing," responds BoJack, as viewers become very much aware of the fact that he is afraid of being forgotten ("Later"). From this point of view, BoJack is the animal of the fable. One trait defines him and determines his end. On the other hand, we are not shown what that end will be, even though all signs point to suicide. His idol, Secretariat, committed suicide when he was banned from racing. BoJack's constant movement, inspired by fear of nothingness, of oblivion, is what Akira Lippit describes with his animetaphor: The animation of an animal which moves frantically in order for it not to be forgotten. This movement frustrates the frame of the fable. Bojack ultimately is propelled onward and does not submit to his predictable fate as a fabulist character. This use of defamiliarization in combination with the entanglement characteristic of wildness helps accomplish this transcendence of the fabulist formula, calling attention to the incompatibility of animals' misplaced evolutionary proficiencies as they work human jobs. This amounts to an estrangement of roles that would otherwise slip automatically into the formulaic pattern of the fable. Wildness challenges the concept of unity through sameness, and invites alternative paths, negating the set fabulist roles.

\section{The Chase}

One of the best examples of this pure movement is the chase cartoon. Chuck Jones' Pepé Le Pew cartoons, which feature the titular skunk's "self-conscious pursuit of the pursuit itself” (Thompson 152), provide a textbook case study. Pepé Le Pew's signature chase-in which he bounds lyrically through streets and meadows to lilting music, while his exhausted victim loses ground-expresses the theme of the "French" skunk's cartoon series in a single fluid movement. This kind of animal movement, captured in the cartoon-perhaps more than in other cinematic representations-allows animal presence to be imagined and remembered in the media, after its disappearance in society. 

understanding the link between BoJack Horseman and cartoon history: "The crossspecies chase structures dozens of cartoon series" and "is authorized and naturalized by the traditional predatory relationships of nature" (Thompson 142-143). But when it comes to Who Framed Roger Rabbit and BoJack Horseman, the natural predation typical of nature is already at a far remove. Norman Klein casts the relations of power instead in the discourse of capitalism ("Hybrid Cinema" 212). Therefore, within the predatory relationship in the chase, the "contract player (represented by Bugs) is prey to Elmer (dumb boss)" (Klein, "Hybrid Cinema" 215). BoJack's crazed pursuit of fame and meaning, and his attendant flight from oblivion, is counterbalanced by the steady and blissfully directionless recreational jogging enjoyed by background characters who inspire BoJack to change. His search for meaning, often manifested in his soliloquies about running-whether to escape something, or simply to "keep living forward" ("Live Fast, Diane Nguyen")-is spurred by his position in the "industry." Both literally as an actor and metaphorically as a horse, he has outlived his purpose. He has been chewed up and spat out, and his claim to fame, his recognizable face, is all that remains of his marketability. This aspect is laid bare when the creators 
of the film-within-the-show Secretariat electronically appropriate his facial features as a contractual back-up plan in case something goes wrong during the production. In the end, the company uses visual effects to make the movie, while BoJack's talents as an actor are not even used. He is a worker dispossessed of his craft. He is empty and unfulfilled, and this is why he chases after meaning. With this in mind, Klein's interpretation of the chase as a predatory relationship in the industrial schema of cartoons and capitalism is a perfect lens through which to approach the chase in BoJack.

The ultimate emptying happens when BoJack is transposed into the world of the Looney Tunes chase cartoon, and he must give up all the characteristics he, a horse, would presumably need to participate in a chase. In the context of the chase, the most important episode is "Fish Out of Water" (season 3, episode 4), in which BoJack spends a weekend under the ocean at a film festival. In this experimental episode, the plot hinges on a Looney Tunes-inspired chase sequence. Once BoJack relocates to this underwater world, there is no dialogue at all. He can neither communicate nor subsist (he can't speak, he doesn't have the correct currency, he cannot eat, smoke or drink; in other words, he enters a land of Shklovskian estrangement, which allows him to access deeper meaning more readily). He encounters a factory worker, a male seahorse, on a bus, and helps him give birth to several babies. When one is inadvertently left behind, BoJack begins his episode-long chase after the father of the baby seahorse. Along the way, he becomes attached to the child and feels fulfilled when taking care of him, in contrast to the perpetual despair he usually feels. The chase scene is comical and ornamentally animated, and relies on the traditional tools of both the Looney Tunes and slapstick humor. What makes this chase special is the way that BoJack's character builds on the traditional cartoon chase (whether it is a primal predatory chase, or a love chase, like Pepé Le Pew's). BoJack's habitual flight from despair is counterbalanced with a chase after meaning. This encounter with the male seahorse and his children undoes all the impossibilities that cause BoJack pain in the rest of the show. The artificiality of his TV show's premise (a horse as the single father of human children) and the assumption that he must be surrounded by people who adore him in order to be happy are both confounded by the underwater chase. In this alternate universe, BoJack finds an alternate self-a seahorse, who, by nature, even as a man, can bear his own children and happily love them. This is the impossible made possible in an alternative reality. Furthermore, BoJack believes that he cannot find meaning and that his character is inherently bad. This, too, is confounded in the underwater chase, in which BoJack sacrifices his own safety to save the seahorse baby, who begins to love BoJack as a father. After inheriting Pepé Le Pew's emasculating and eternal chase for meaning, BoJack transcends it with this selfless chase, which ultimately fulfills. Tellingly, this episode takes place far away from Los Angeles, where BoJack only plays out the imaginary roles bequeathed by his predecessors in Hollywood. In this remote underwater world, he can escape the legacy that haunts his character and his species while at the same time subverting the tradition of the Looney Tunes chase sequence by attaining a small share of meaning through selflessness instead of all-encompassing desire that normally characterizes his way of life.

The running motif is constructed with the help of Shklovskian defamiliarization. Like Shklovsky's example of making a stone "stoney" again through subtracting its recognizable features, BoJack Horseman makes BoJack, the horse, "horsey" again by subtracting from him his natural capability to run. His running is made difficult and unnatural. His role models are also unnatural: The elderly monkey decked out in 
running garb who jogs past BoJack's house every day tells him that running gets a little bit easier every day. The mustangs who run shirtless through the desert in the final scene of the third season are also made strange by their running shorts, replacing the supposedly "wild" with the somewhat cultured. By imagining the supposedly "natural" ability of the horse to run, we uncover how unnatural everything about the horse really is. Humans artificially bred his ancestors for various uses, and now BoJack must exist in a post-horse culture. It is not surprising that the literary horse depicted by Leo Tolstoy was the foremost example chosen by Shklovsky to present his theory of literary estrangement. It's furthermore not surprising that Tolstoy chose the horse as his vehicle for a critique of personal property based on Jonathan Swift's satirical depiction of the Houyhnhnms (the horse people) in Gulliver's Travels (1726).

The chase, in his life as a washed-up actor and in his life as a horse, is a result of BoJack's position in a capitalist society that propagates the myth of the "race." Like Tolstoy's estranged horse-narrator, it is no surprise that a critique of this "race" would come "straight from the horse's mouth."

\section{Capitalism}

31 As mentioned above, Norman Klein envisions the predatory chase as a microcosm of the capitalist world of animation, which he calls "fundamentally industrial," since it revolves around "repetitive action[s]" and since ownership of the means of production is significantly removed from the artists, with "contracts that say the studio owns whatever 'creative' ideas are generated. Beneath the ergonomics and cheery carpeting, it is still a factory" ("Hybrid Cinema" 212). BoJack's precursor Who Framed Roger Rabbit (1988) dramatizes this cartoon class struggle. ${ }^{3}$ Paul Wells has argued that the use of animals in cartoons allows for "social embedding": "[E]xposing notions of consensus and the limits of democratic existence ... the vehicle for what I call the political carnivalesque" (175). Roger Rabbit, a period piece set in 1940s' Los Angeles, the golden age of the Looney Tunes, provides an excellent example of this social embedding. In the film, the "toons" are real-live actors, who are second-class citizens exploited for their movie work every day before returning to their spectral imaginary home-“Toon Town," which doubles as a dreamland and a lawless ghetto beyond the borders of "realistic" Hollywood.

Originally inspired by the live action/cartoon hybrid You Ought to Be in Pictures (1940), Roger Rabbit explores the coexistence between animated creations and historical Los Angeles. You Ought to Be in Pictures similarly revolves around Porky the Pig's contract at Warner Brothers. Daffy Duck convinces Porky that he is exploited, that he could be a real star in the movies, and that he should tear up his contract with Warner Brothers. Daffy's ulterior motive is that he could have more lead roles with Porky out of the way. Porky eventually reneges on his ill-advised departure from Warner Brothers and begs for his contract back (Leon Shlesinger mercifully agrees). The theme of the exploitation of animal cartoon characters was already developed in this earlier cartoon, and Roger Rabbit takes the premise a huge step forward, giving the toons their own society, Los Angeles neighborhood, and social status. The toons, who are Hollywood's true workers, actually seize the means of production in Roger Rabbit.

The most disturbing element of the film is the notion that toons cannot die-that is, until the villain creates a special chemical mixture into which they can be "dipped" and 
dissolved. This denial of death is reminiscent of philosophy on animal death. Gottfried Wilhelm Leibniz, for example, claimed that animals, since they exist as a category and not as individuals, never die and simply exist continually (Lippit 34). In Roger Rabbit, this immortality is accentuated when the toons' creator dies and leaves the whole cartoon business to the toons. The conflict arises when the villain tries to obstruct the inheritance. Ultimately, the death of the human gives way to communism in the storythe toons will own the means of production. Although not all the toons are animals, they do represent the other in the same manner-they have little use for money, but they need to solve the problem of exploitation. The imagined integration of human and toon or human and animal cultures (such as in BoJack) ultimately are suggestive of a reality outside of the capitalist mindset. If we remember Klein's conflation of Los Angeles' erased communities with the drafts thrown in the garbage during the making of a cartoon, we can imagine the marginalized toons as an embodiment of all the communities exploited or marginalized for the sake of capitalistic enterprise in Los Angeles.

\section{Post-Human Memory}

In the context of capitalism, with which I link the chase cartoon, and especially BoJack's never-ending chase after meaning, the inevitable result is a space of memory and trauma. The BoJack Horseman episode "Live Fast, Diane Nguyen" explores such a space. In the only episode that takes place in Boston, BoJack accompanies Diane to her family home so she can arrange a funeral for her father, whom she blames for all of her coming-of-age strife. Once there, despite her efforts, her slow-witted brothers manage to steal the body, miss the funeral, and instead have their father turned into a barrel of chum, which they intend to throw at Derek Jeter's "fat face" as vengeance for some deep wound in their collective Bostonian masculinity. ${ }^{4}$ After a frustrating encounter with her brothers and BoJack, Diane steals the truck in which the chum barrel is stored and speeds away in anger. BoJack is the only one who knows to where she has disappeared. When BoJack finds Diane, they sit atop a landfill and gaze at the starry sky while they try to reckon with the wrongs done to them by their forbears. Just like the ever-growing trash heap beneath them, the consequences of their fathers' negligence have become their responsibility. In this scene, where we normally see a backdrop of the Hollywood hills behind a BoJack-and-Diane tête-à-tête, a trash heap along with the actual remains of Diane's father (the presumed source of all her problems) are substituted for the beauty of Los Angeles. ${ }^{5}$ BoJack tells Diane that the reason people live in Los Angeles is because, just as we didn't willingly choose our families, we don't need to be responsible for or to them. He praises the superficiality of the city they call home, which is in effect another heap of waste-the byproducts of our parents' generation and their failures, all those people who are damaged or in need of escape, thrown together as a motley assortment of half-developed people, much like the half-assimilated and varied animals and humans in BoJack's Los Angeles.

This contemplation of existential despair, which is capped by BoJack's assuagement: "at least your father can never hurt anyone again," is undercut with old Hollywood-style humor. Immediately following this statement, the remains of Diane's father roll down a hill and follow an unlikely path that will seemingly lead directly to Derek Jeter (who sweetly helps a goat in old women's clothing cross the street). At the last moment, the 
barrel knocks out the goat in Jeter's place, and in a comic fulfillment of the demonization of the Yankees espoused by the caricatured Bostonians who are Diane's brothers, Jeter glances in either direction before abandoning his good-Samaritan persona and stealing the unconscious goat's purse. But even this can be read as an investigation of responsibility.

Even after we are dead or our actions have been completed, the consequences, such as the trash, the waste, and the effects on our children's emotional health, continue. This is the human effect on the environment made light of by the substitution of animals into human positions of responsibility. BoJack's mother, Beatrice, also a horse, is an heiress to a sugar cube fortune, a clever superimposition of an industry historically troubled by ethical issues onto an animal, who is herself a product of the human oppression of breeding, work, and spectator sport. The fourth season, which perhaps stresses psychoanalytical themes as well as metabiosis most, explores Beatrice's past while and after BoJack returns to Beatrice's childhood home in Michigan. ${ }^{6}$ We see her childhood reenacted simultaneous to BoJack's time there, as if time is artificial and when we occupy a space, we share it with all its former occupiers ("The Old Sugarman Place"). We find that contrary to her own ideas, her parents forced her to conform to ultra-conventional forms of behavior, exploiting her feminine beauty by attempting to marry her off to the son of a coffee creamer company's owner in an attempt to make a lucrative business deal. All this is laid bare at her debutante's ball, when she is made to perform her skills as a show jumper. This combined satire of gender inequality and animal exploitation shows the source of Beatrice's own psychological injury to which she reacts by running away with BoJack's father, who impregnates her, marries her, and is ultimately unable to make her happy. After this, she blames her loss of beauty and fulfillment on BoJack, passing her trauma onto him ("Time's Arrow"). At the end of BoJack's time in his mother's Michigan home, he talks to Diane on the phone who paraphrases BoJack's praise for Los Angeles during the landfill episode discussed earlier. Only Diane's words are able to snap BoJack out of his dark exploration of memory and responsibility during his time in the Michigan house ("The Old Sugarman Place"). Once again, he escapes to Los Angeles, where he attempts to erase the influence of memory on his life.

\section{Conclusion}

BoJack Horseman is not about animals at all. The themes dealt with in the most serious episodes are those of moral responsibility, the inheritance of our parents' moral faults, the nature of despair and loneliness, and whether our unconscious intentions are demonstrated in our inadvertently harmful actions. These are the concerns of psychoanalysis. As I have shown, these concerns motivate a convergence of topoi in BoJack Horseman, which ultimately yield a Los Angeles populated by the animal ghosts of Warner Brothers cartoons. The emergence of cartoon animation coincided with society's mourning for the disappearance of animals. More so than in live-action film, cartoon animation is characterized by the idea of animetaphor, which Akira Lippit introduces in his study of technology and the philosophy of the animal. The onset of Modernism, and especially Freudian unheimlich and Russian formalist fascination with the wilder, unfamiliar perspectives, explain the displacement of the animal to visualized narrative, and especially to animation. The city of animation, Los Angeles, is 
home to the ghosts of this history of uncanny relationships between animals and cinema, or between humans and animals in cartoons.

Figure 1 illustrates the simultaneously spectral and material traces of animals in Los Angeles. This mural on the side of a live poultry butcher shop is inhabited by animals suspended in motion, all participating in the chase, the hunt. Only they are humorously aware that the object of the hunt is themselves. Foghorn Leghorn advises customers to buy freshly killed poultry, not frozen. This mural shares uncanny similarity with the BoJack Horseman episode "Chickens" (season 2, episode 5), where a chicken farm is run by chickens who claim to provide a dignified life for the poultry they raise for slaughter. ${ }^{7}$ Both the episode and mural in Figure 1 are examples of the cannibalism inherent in capitalist consumption. These animated figures herald their own disappearance long after the era of the original Looney Tunes has passed.

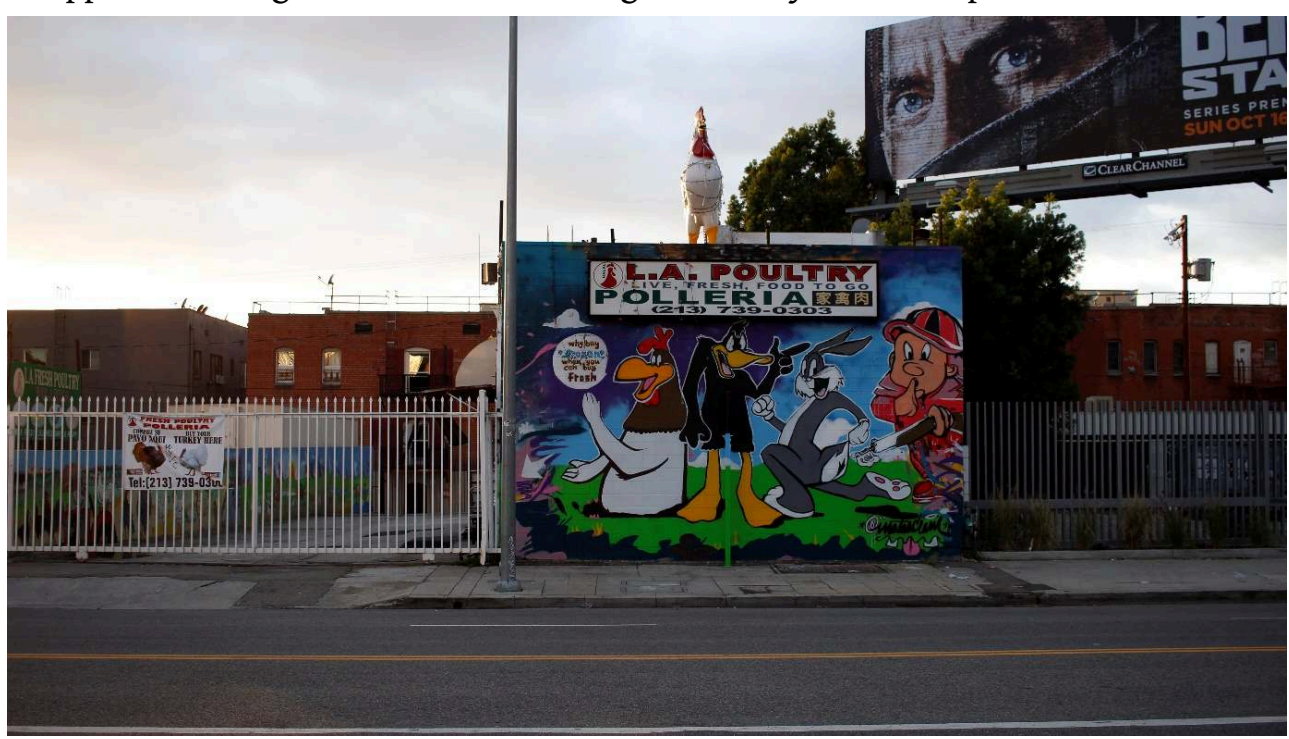

Fig. 1: Mural on the side of a poultry shop in Los Angeles. Photo taken by Albert Vazquez.

\section{BIBLIOGRAPHY}

Barthes, Roland. "Death of the Author." Image-Music-Text. New York: Hill \& Wang, 1977. Print. Baudrillard, Jean. “The Animals.” Simulacra and Simulation. Trans. Sheila Faria Glaser. Ann Arbor: U of Michigan P, 1994. Print.

Benesch, Klaus, "Writing Grounds: Ecocriticism, Dumping Sites, the Place of Literature in a Posthuman Age." Public Space and Ideology in American Culture. Ed. Miles Orvell and Jeffrey L. Meikle. New York: Rudopi, 2009. Print.

Berger, John. “Why Look at Animals?” About Looking. New York: Vintage, 1980. 3-30. Print. Cavalcanti, Alberto. "Comedies and Cartoons." Footnotes to the Film. Ed. Charles Davy. London: Lovat and Dickson, 1937. 71-86. Print. 
“Chickens.” Writ. Joanna Calo. Dir. Mike Roberts. BoJack Horseman. Netflix, 2015. Stream.

Cohen, Karl F. Forbidden Animation: Censored Cartoons and Blacklisted Animators in America. Jefferson, NC: McFarland, 2004. Print.

Derrida, Jacques. The Animal that Therefore I Am. Trans. David Wills. New York: Fordham UP, 2008. Print.

Eagan, Daniel. America's Film Legacy. New York: Continuum, 2010. Print.

Emerson, Caryl. “Shklovsky's ostranenie, Bakhtin's vnenakhodimost' (How Distance Serves an Aesthetics of Arousal Differently from an Aesthetics Based on Pain)." Poetics Today 26.4 (2005): 637-664. Print.

"Fish Out of Water." Writ. Elijah Aron and Jordan Young. Dir. Mike Hollingsworth. BoJack Horseman. Netflix, 2016. Stream.

Gunning, Tom. "Phantom Images and Modern Manifestations: Spirit Photography, Magic Theater, Trick Films, and Photography's Uncanny." Fugitive Images: From Photography to Video. Ed. Patrice Petro. Bloomington: Indiana UP, 1995. 42-71. Print.

Jones, Chuck. Chuck Amuck. New York: Farrar, Strauss and Giroux, 1999. Print.

Klein, Norman. The History of Forgetting: Los Angeles and the Erasure of Memory. New York: Verso, 1997. Print.

Klein, Norman. "Hybrid Cinema: The Mask, Masques, and Tex Avery." Reading the Rabbit: Explorations in Warner Bros. Animation. Ed. Kevin S. Sandler. New Brunswick, NJ: Rutgers University Press, 1998. 209-220. Print.

“Later.” Writ. Raphael Bob-Waksberg. Dir. Martin Cendrada. BoJack Horseman. Netflix, 2014. Stream.

Lippit, Akira Mizuta. Electric Animal: Toward a Rhetoric of Wildlife. Minneapolis: U of Minnesota P, 2008. Print.

“Live Fast, Diane Nguyen.” Writ. Caroline Williams. Dir. Joel Moser. BoJack Horseman. Netflix, 2014. Stream.

Murphy, Patrick. “"The Whole Wide World was Scribbed Clean': The Androcentric Animation of Denatured Disney." From Mouse to Mermaid: The Politics of Film, Gender, and Culture. Bloomington: Indiana UP, 1995. 125-136. Print.

“The Old Sugarman Place." Writ. Kate Purdy. Dir. Anne Walker Farrell. BoJack Horseman. Netflix, 2017. Stream.

Shklovsky, Viktor. Theory of Prose. Trans. Benjamin Sher. Intro. Gerald. L. Bruns. Normal, IL: Dalkey Archive P, 1990. Print.

Snyder, Gary. The Practice of the Wild: Essays. Berkeley, CA: Counterpoint, 2004. Ebook.

Thompson, Kristen Moana. “'Ah Love! Zee Grand Illusion': Pepé le Pew, Narcissism, and Cats in the Casbah." Reading the Rabbit: Explorations in Warner Bros. Animation. Kevin S. Sandler. New Brunswick, NJ: Rutgers UP, 1998. 137-153. Print.

“Time's Arrow.” Writ. Kate Purdy. Dir. Aaron Long. BoJack Horseman. Netflix, 2017. Stream. Vaingurt, Julia. Wonderlands of the Avant-Garde: Technology and the Arts in Russia of the 1920s. Chicago, IL: Northwestern UP, 2013. Print. 
Wells, Paul. The Animated Bestiary: Animals, Cartoons, and Culture. New Brunswick, NJ: Rutgers UP, 2009. Print.

Who Framed Roger Rabbit. Dir. Robert Zemeckis. Touchstone Pictures, 1988. Stream.

\section{NOTES}

1. My discussion concerns cinematic history and theory along with examples from film and television. For my project, which concerns the representation of animals in moving images, the difference between television and film is not relevant. Both film and television, at least in the case studies conducted here, include projections of the moving image of the animal. Although film and television series have different effects due to their singular or extended viewing processes, these differences will not be relevant here.

2. There is an implicit neoliberal didacticism in BoJack Horseman. Although these various species were formed for other walks of life, they were still able to make it in Los Angeles.

3. Alhough there is no room in this study for discussion of less well-known influences in the line of succession in cartoon history leading to BoJack, I would still like to highlight Fritz the Cat (1972). The racy, psychedelic meanderings of this full-length cartoon movie featured, similar to BoJack, the main character having "sex with all kinds of animals" (Cohen 81): "The film is full of bare-breasted females of various species, foul language, cops with pig heads and outrageous images of softcore sex" (Cohen 82). The film was envisioned as a way to "lampoon our phony values," and to be the "antithesis of a Disney animated feature" (Cohen 81). Newsweek called it a "celebration of urban decay" (Cohen 84). BoJack doesn't go as far as Fritz in terms of pornographic content or violations of narrative expectations via the device of hallucinogen-spurred trips (although one or two of these sequences do mark the darkest episodes of BoJack). BoJack seems to strive for mass palatability, while skirting the edge of madness and nihilism only in a few moments. The show may, however, be called an exploration (if not a "celebration") of urban decay.

4. From 1995 to 2014, Derek Jeter played for the New York Yankees, the archnemesis of the Boston Red Sox. Since he won five World Series titles with the Yankees, he represents a Bostonian masculine inferiority anxiety. However, it should also be pointed out that during his time in New York, the Red Sox broke the "Curse of the Bambino," a superstition that developed from Boston's failure to win a World Series title after selling Babe Ruth to the Yankees in December 1919-until finally succeeding in 2004.

5. This metonymic substitution of a landfill for the city of Los Angeles evokes dystopian visions of a post-human world. Klaus Benesch's study "Writing Grounds" explores the evolution of dumping sites in literature. These sites can serve as a catalyst for nostalgia for or distancing from the past, and can be embraced as a source of artistic creation or as a representation of posthuman reality (446).

6. "Metabiosis" is Russian futurist Velimir Khlebnikov's term for "the influence of a past event on subsequent events that take place in the same geographic location," or "the influence through absence" (Vaingurst 116).

7. In a TV ad in the episode, the chicken-spokesman of "Gentle Farms" explains to his young chicken-son that "friend" chickens are distinguished from "food" chickens through the administration of hormones, which makes the latter into "meat," "erasing any moral gray area." 


\section{ABSTRACTS}

In this paper, I trace themes of the animetaphor. I interpret Akira Mizuta Lippit's term as a moving image of the re-membered animal that projects a collective anxiety of oblivion for all animals, including humans. I begin with an exploration of this theme with respect to early cinema and the philosophical and psychological movements that accompany it. I then investigate more contemporary examples of these models in three case studies-Chuck Jones' characters in the Looney Tunes, the movie Who Framed Roger Rabbit, and the Netflix series BoJack Horseman-to explore the imagined city of Los Angeles as a cartography of animal ghosts, invented and reinvented as semiotic machines, which force us to look at animals as ourselves and at ourselves as animals. Mechanisms of mass cultural memory are at work in the cinematic history of Los Angeles, and animation is often a projection of those memories. The link between psychoanalysis, the emergence of cinema, and modernism during the early part of the twentieth century serves as the philosophical-aesthetic background for my approach to social and artistic themes that haunt cinematic and real space in Los Angeles through the movement of animated animals. I argue that the fascination with animal movement of early cinema and cartoon animation suggest a particular function of cinema, and even more so cartoon animation, to remind us of repressed sensations and images from our collective unconscious.

\section{INDEX}

Keywords: Los Angeles, animation, BoJack Horseman, Who Framed Rogger Rabbit, Looney Tunes

\section{AUTHOR}

\section{LAUREL SCHMUCK}

Laurel Schmuck is a Ph.D. candidate in the Comparative Studies in Literature and Culture program at the University of Southern California. Her dissertation, "Plants and Animals in Leo Tolstoy's Late Prose," explores the connections between the symbolic uses of animals and plants as well as non-male and non-human voices and the narrative structures of Tolstoy's late fiction. Her other research interests include animal philosophy, animals in nineteenth-century French literature, and animals in American and Russian cartoons. 